\title{
Metabolomic And Antioxidant Enzyme Activity Changes In Response To Cadmium Stress Under Boron Application of Wheat (Triticum Aestivum)
}

Shiyu Qin ( $\sim$ qinsy0418@henau.edu.cn )

Henan Agricultural University https://orcid.org/0000-0003-2458-9625

Yafang Xu

Henan Agricultural University

Zhaojun Nie

Henan Agricultural University

Hongen Liu

Henan Agricultural University

Wei Gao

Henan Agricultural University

Chang Li

Henan Agricultural University

Peng Zhao

Henan Agricultural University

Research Article

Keywords: cadmium stress, boron, wheat, metabolomics, antioxidant enzyme activity

Posted Date: August 24th, 2021

DOI: https://doi.org/10.21203/rs.3.rs-763783/v1

License: (c) (i) This work is licensed under a Creative Commons Attribution 4.0 International License. Read Full License 


\section{Abstract}

Boron (B) has previously been shown to inhibit cadmium (Cd) uptake in wheat, while the underlying physiological mechanism behind this phenomenon is unclear. Here, we investigated the alteration with B application in growth, Cd uptake, MDA content, antioxidant enzyme activities and small molecule metabolites under $\mathrm{Cd}$ stress. The results showed that the wheat growth were significantly weaker under $\mathrm{Cd}$-treated than that without $\mathrm{Cd}$-treated. B application can improve the wheat growth under Cd stress. In addition, B application decreased Cd concentrations and MDA concentrations of shoot and root. These results suggest that $B$ can inhibit the absorption of $\mathrm{Cd}$ and mitigation of $\mathrm{Cd}$ toxicity to promote plant growth, especially in the roots. Meanwhile, the key enzyme activities including SOD and POD significant increased under Cd treatments, while decreased under B treatments. Further, root differential metabolites were identified with Liquid Chromatograph Mass Spectrometer (LC-MS). A total of 198, 680 and 204 of the differential metabolites were isolated between $\mathrm{CK}+\mathrm{B}$ and $\mathrm{CK}$ treatment, $\mathrm{CK}+\mathrm{Cd}$ and $\mathrm{CK}$ treatment and $\mathrm{CK}+\mathrm{Cd}+\mathrm{B}$ and $\mathrm{CK}+\mathrm{Cd}$ treatment respectively. The metabolites with up-accumulation in $\mathrm{B}$ application $(C K+C d+B)$ roots were mainly galactaric acid, citric acid, N6-Galacturonyl-L-lysine, D-Glucose, while the metabolites with down-accumulation were mainly threoninyl-tryptophan and $\mathrm{C} 16$ sphinganine. The differential metabolic pathways were mainly concentrated in linoleic acid metabolism, galactose metabolism, sphingolipid metabolism, glycolysis/gluconeogenesis, propanoate metabolism in diabetic complications between $\mathrm{CK}+\mathrm{Cd}+\mathrm{B}$ treatment and $\mathrm{CK}+\mathrm{B}$ treatment. The data suggested that B alleviates $\mathrm{Cd}$ toxicity in winter wheat by inhibiting Cd uptake, increasing antioxidant enzyme activity and changing metabolites.

\section{Introduction}

It is well known that cadmium (Cd) is one of the heavy metals and have high toxicity for human and plant health. For human, Itai-itai is the best known Cdinduced disease, other diseases like renal dysfunction, osteoporosis, and bladder cancer (Feki-Tounsi and Hamza-Chaffai 2014). The most important cause of these diseases is due to long-term consumption of Cd-contaminated food. Studies show that food as the main source of Cd exposure contributed about $90 \%$ of the total Cd intake in the general population (Clemens et al. 2013; He et al. 2013). Therefore, it is an important measure for human food safety to prevent the absorption of $\mathrm{Cd}$ in crops and its migration to edible parts. In plant, $\mathrm{Cd}$ can enter root and be transported to the ground through the various $\mathrm{Cd}$ transport systems, such as transporters for uptake in roots (OsNramp5, HvNramp5, OsIRT1, OsIRT2, OsNramp1 and OsCd1), transporters for vacuolar sequestration in roots (OsHMA3), transporters involved in root-to-shoot translocation (OsHMA2, OsHMA3, OsZIP7 and OsCAL1) and transporters for distribution to the grains (OsHMA2, OsLCT1, OsZIP7, and OsCCX2) (Ma et al. 2021). Cd affects plant growth and development due to its toxic effects on different metabolic and physiological processes, such as causing leaf chlorosis, necrotic lesions, wilting, inhibited root elongation, and reduced biomass (Qin et al. 2020a; Rizwan et al. 2016). Therefore, reducing the Cd uptake or migration to edible sites is the key factor to ensure no Cd pollution in grains in polluted soil, and is also stop the migration to the food chain.

Many agronomic strategies have been shown to reduce $\mathrm{Cd}$ absorption in crop, such as soil removal and replacement, soil turnover and dilution, soil dressing, chemical washing, phytoremediation and inorganic amendments (Wang et al. 2011; Hseu et al. 2010; Uraguchi and Fujiwara 2012; Rizwan et al. 2016). Among these strategies, inorganic amendments was also reported as a low-cost but effective approaches. For example, there is an efficiently competes between $\mathrm{Cd}$ with iron (Fe), manganese (Mn), zinc ( $\mathrm{Zn})$, and calcium ( $\mathrm{Ca}$ ) in uptake and the application of these micronutrients commonly decreases the uptake and accumulation of Cd (Qin et al. 2020; Meda et al. 2007; Astolfi et al. 2012; Duan et al. 2018). Silicon (Si) fertilizer or nana-silicon application could reduce Cd absorption and alleviate the toxicity to crop (Ma et al. 2015; Wang et al. 2015). It was also reported that selenium (Se) fertilization could reduce Cd uptake and mitigates Cd toxicity in crop (Hu et al. 2014; Lin et al. 2012). The underlying mechanism of effects of these elements on Cd toxicity and accumulation may include 1) competitive uptake via the same transport system (Fahad et al. 2015; Qin et al. 2020a), 2) increase the antioxidative capacity and photosynthetic characteristics (Lin et al. 2012; Qin et al. 2018), 3) induce the formation of phytochelatin and cysteine-rich peptides (Jasinski et al. 2003; Semane et al. 2007).

Boron (B) is an essential micronutrient for plant growth. It is essential for the structural and functional integrity of the cell wall and membranes, photosynthesis, cell division and elongation, nitrogen and carbohydrate metabolism, etc (Shireen et al. 2018). In recent years, it has been found that B plays an important role in alleviating abiotic stress in plants. For example, B alleviates aluminum (Al) toxicity by promoting root alkalization in transition zone via polar auxin transport (Li et al. 2018) and B alleviate Cd accumulation and toxicity by improving oxidative stress and suppressing Cd uptake and transport (Chen et al. 2019). Likewise, our previous work showed that B could inhibits Cd uptake by regulating gene expression in wheat (Triticum aestivum L.) (Qin et al. 2020b). However, the physiological mechanism why B inhibits Cd absorption is yet to be investigated. To understand how B influences the uptake of Cd and Cd toxicity, antioxidant substances and antioxidant enzyme activity were studied and the different metabolites and metabolic pathways was analyzed.

\section{Materials And Methods}

\section{Plant material and experimental conditions}

Hydroponic experiment was carried out on Henan Agricultural University, Zhengzhou, China. Wheat seeds (cv Zhengmai 379, Triticum aestivum L.) were surface-sterilized in $0.5 \% \mathrm{Na}$-hypochlorite for $15 \mathrm{~min}$ and seeds were then rinsed carefully with deionized water. The seeds were germinated on a plastic net floating on deionized water and seven-day-old rice seedlings with similar size were transfer to the incubators to growth in a controlled chamber with photoperiod of $16 \mathrm{~h} / 8 \mathrm{~h}$ (day/night) at $25^{\circ} \mathrm{C} / 20^{\circ} \mathrm{C}, \mathrm{RH} 75 \%$, and light intensity of $200 \pm 25 \mu \mathrm{mol} \mathrm{m}^{-2} \mathrm{~s}^{-1}$. The full nutrient solution (FNS) contained: $4.0 \mathrm{mM}$ $\mathrm{Ca}\left(\mathrm{NO}_{3}\right)_{2} \cdot 4 \mathrm{H}_{2} \mathrm{O} \otimes 6 \mathrm{mM} \mathrm{KNO}_{3} \otimes 1 \mathrm{mM} \mathrm{NH}_{4} \mathrm{H}_{2} \mathrm{PO}_{4}, 2 \mathrm{mM} \mathrm{MgSO}_{4} \cdot 7 \mathrm{H}_{2} \mathrm{O}, 46.2 \mu \mathrm{M} \mathrm{H}_{3} \mathrm{BO}_{3}, 9.1 \mu \mathrm{M} \mathrm{MnCl}_{2} \cdot 4 \mathrm{H}_{2} \mathrm{O}, 0.3 \mu \mathrm{M} \mathrm{CuSO} \cdot 5 \mathrm{H}_{2} \mathrm{O}, 0.8 \mu \mathrm{M} \mathrm{ZnSO} \cdot 7 \mathrm{H}_{2} \mathrm{O}, 100 \mu \mathrm{M}$ FeNaEDTA, $0.2 \mu \mathrm{M}\left(\mathrm{NH}_{4}\right)_{6} \mathrm{Mo}_{7} \mathrm{O}_{24} \cdot 4 \mathrm{H}_{2} \mathrm{O}$. The solution $\mathrm{pH}$ was adjusted to 6.5 using $1 \mathrm{M} \mathrm{HCl}$ or $\mathrm{NaOH}$. Half-strength nutrient solution was applied for the first 7 $\mathrm{d}$ and changed to full strength solution for another $4 \mathrm{~d}$. Each treatment was replicated four times. Five treatments was set as follow: (1) CK (without $\mathrm{B}$ ); (2) $\mathrm{CK}+\mathrm{B}$ (B was added after 7 days of culture); (3) CK+Cd (Cd was added after 7 days of culture); (4) CK+Cd+B (Cd and B were added after 7 days of culture); (5) preB+Cd (B seven-day pretreatment before $\mathrm{Cd}$ exposure). $\mathrm{Cd}$ was applied as $\mathrm{CdCl}_{2}$ solution with a final Cd concentration of $5 \mu \mathrm{M}$. After $23 \mathrm{~d} \mathrm{Cd}$ treatments, root and leaf samples rinsed in distilled water were harvested and used fresh or kept frozen in liquid $\mathrm{N}_{2}$ for various biochemical assays. 


\section{Cd concentration analysis}

Plants were divided into root and shoot fractions and oven-dried at $70^{\circ} \mathrm{C}$ to constant weight. These fractions were then digested with mixed acid $\left(\mathrm{HNO}_{3}: \mathrm{HClO}_{4}\right.$ $(4: 1, \mathrm{v}: \mathrm{v}))$ in a Microwave Digestion System. Cd concentration was determined by graphite furnace atomic absorption spectrometry (GFAAS). The translocation factor (TF) was calculated as follows: $\mathrm{TF}=$ shoot $\mathrm{C}_{\mathrm{Cd}} /$ root $\mathrm{C}_{\mathrm{Cd}}$.

\section{Malondialdehyde (MDA) determination}

The level of lipid peroxidation is estimated as the amount of MDA determined by the thiobarbituric acid (TBA) reaction as described by Qin et al. (2018). Briefly, $500 \mathrm{mg}$ of fresh root or shoot samples was homogenized with $2 \mathrm{~mL} 5 \% \mathrm{v} / \mathrm{v}$ trichloroacetic acid (TCA) and centrifuged at $10,000 \times \mathrm{g}$ for $10 \mathrm{~min}$. Then, 1 $\mathrm{mL} 0.5 \% \mathrm{v} / \mathrm{v}$ TBA in $20 \% \mathrm{v} / \mathrm{v}$ TCA was added to $1 \mathrm{~mL}$ supernatant and the homogenate was boiled for 30 min at $95^{\circ} \mathrm{C}$. The mixture was followed by an immediate cooling on ice to stop the reaction and centrifuged at 10,000×g for $5 \mathrm{~min}$. The absorbance was determined at $450 \mathrm{~nm}, 532 \mathrm{~nm}$ and $600 \mathrm{~nm}$ and MDA concentration was estimated by the formula: $\mathrm{MDA}(\mu \mathrm{mol} / \mathrm{g} \mathrm{FW})=6.45\left(\mathrm{OD}_{532}-\mathrm{OD}_{600}\right)-0.56 \mathrm{OD}_{450}$.

\section{Antioxidant enzyme activities}

Antioxidant enzyme activities (SOD, CAT and POD) in roots and leaves were determined spectrophotometrically according to previous literatures and make some modifications (Molins et al. 2013; Wu et al. 2017). Fresh tissues ( $0.5 \mathrm{~g})$ were ground in liquid nitrogen to a fine powder using a mortar and pestle. The powder was transferred to a pre-cooled $\left(4^{\circ} \mathrm{C}\right)$ mortar and pestle with $5 \mathrm{~mL}$ of $50 \mathrm{mM}$ phosphate buffer $(\mathrm{pH} 7.8)$, containing $0.12 \mathrm{mM} \mathrm{EDTA}$ and $2 \%(\mathrm{w} / \mathrm{v})$ polyvinylpolypyrrolidone. The homogenate was centrifuged at $12,000 \times \mathrm{g}$ at $4^{\circ} \mathrm{C}$ for $20 \mathrm{~min}$. The supernatant was used for assays of the antioxidant enzyme activities. The assay of SOD was carried out briefly as follows: the assay mixture (total $3 \mathrm{~mL}$ ) for SOD contained $0.05 \mathrm{M}$ phosphate buffer, containing $12 \mu \mathrm{M}$ EDTA and $13 \mathrm{mM}$ L-methionine, $75 \mu \mathrm{M}$ nitroblue tetrazolium (NBT), $2 \mu \mathrm{M}$ riboflavin in $5 \mathrm{mM} \mathrm{KOH}$ and $0.05 \mathrm{~mL}$ enzyme extract. Reaction was initiated by placing the glass test tubes in between two fluorescent tubes. By switching the light on and off, the reaction was started and terminated, respectively. The increase in absorbance due to formazan formation was read at $560 \mathrm{~nm}$. The activity was expressed as $\triangle \mathrm{A}_{560}\left(\mathrm{U} \mathrm{mg}^{-1}\right.$ protein min $\left.^{-1}\right)$. CAT activity was assayed. The reaction mixture for CAT comprised of $1.5 \mathrm{~mL}$ of $25 \mathrm{mM}$ phosphate buffer ( $\mathrm{pH} 7.0$ ), $0.3 \mathrm{~mL}$ of $0.1 \mathrm{M} \mathrm{H}_{2} \mathrm{O}_{2}$ and $0.2 \mathrm{~mL}$ of enzyme extract. The change of absorbance value within 210 s was measured at $240 \mathrm{~nm}$ with the blank setting of deionized water. The CAT activity was expressed as $\mathrm{U}$ mg-1 protein $\mathrm{min}^{-1}$. Guaiacol peroxidase activity was determined spectrophotometrically by measuring the oxidation of guaiacol to tetraguaiacol at $470 \mathrm{~nm}$. The reaction mixture contained $1 \mathrm{~mL}$ of $50 \mathrm{mM}$ phosphate buffer $(\mathrm{pH} 5.5), 1 \mathrm{~mL}$ of $0.3 \% \mathrm{H}_{2} \mathrm{O}_{2}, 0.95 \mathrm{~mL} 0.2 \%(\mathrm{v} / \mathrm{v})$ guaiacol, and $0.05 \mathrm{~mL}$ enzyme extract. The change rate of absorbance value was recorded at $470 \mathrm{~nm}$ within $210 \mathrm{~s}$, and the number of reads was recorded every 30 s. A peroxidase activity unit (U) was determined by $\triangle \mathrm{A}_{470}$ changing by 0.01 per minute and the activity was expressed as $\mathrm{U} \mathrm{mg}{ }^{-1}$ protein $\mathrm{min}^{-1}$.

\section{Metabolite extraction and metabolite profiling analysis}

The identification of differential metabolites was performed by Shanghai Lu Ming Biological Technology Co. Ltd. $80 \mathrm{mg}$ accurately weighed sample was transferred to a $1.5 \mathrm{~mL}$ Eppendorf tube. Two small steel balls were added to the tube. $20 \mu \mathrm{L}$ of 2-chloro-l-phenylalanine $(0.3 \mathrm{mg} / \mathrm{mL})$ dissolved in methanol as internal standard and $1 \mathrm{~mL}$ mixture of methanol and water $(7 / 3, \mathrm{v} / \mathrm{v})$ were added to each sample, samples were place at $-20^{\circ} \mathrm{C}$ for $2 \mathrm{~min}$. Then grinded at 60 $\mathrm{HZ}$ for $2 \mathrm{~min}$, and ultrasonicated at ambient temperature for $30 \mathrm{~min}$ after vortexed, then placed at $-20^{\circ} \mathrm{C}$ for 20 min. Samples were centrifuged at $13,000 \mathrm{rpm}$, $4^{\circ} \mathrm{C}$ for $10 \mathrm{~min} .0 .3 \mathrm{~mL}$ of supernatant in a brown and glass vial was dried in a freeze concentration centrifugal dryer. $0.4 \mathrm{~mL}$ mixture of mixture of methanol and water $(1 / 4, v / v)$ were added to each sample, samples vortexed for $30 \mathrm{~s}$, then placed at $4^{\circ} \mathrm{C}$ for $2 \mathrm{~min}$. Samples were centrifuged at $13,000 \mathrm{rpm}, 4^{\circ} \mathrm{C}$ for 5 min. The supernatants $(150 \mu \mathrm{L})$ from each tube were collected using crystal syringes, filtered through $0.22 \mu \mathrm{m}$ microfilters and transferred to LC vials. The vials were stored at $-80^{\circ} \mathrm{C}$ until LC-MS analysis. QC samples were prepared by mixing aliquots of the all samples to be a pooled sample.

An ACQUITY UHPLC system (Waters Corporation, Milford, USA) coupled with an AB SCIEX Triple TOF 5600 System (AB SCIEX, Framingham, MA) was used to analyze the metabolic profiling in both ESI positive and ESI negative ion modes. An ACQUITY UPLC BEH C18 column $(1.7 \mu \mathrm{m}, 2.1 \times 100 \mathrm{~mm})$ were employed in both positive and negative modes. The binary gradient elution system consisted of (A) water (containing $0.1 \%$ formic acid, v/v) and (B) acetonitrile (containing $0.1 \%$ formic acid, $v / v$ ) and (B) acetonitrile (containing $0.1 \%$ formic acid, v/v) and separation was achieved using the following gradient: 0 min, $5 \%$; 2 min, $20 \%$ B; 4 min 25\% B; 9 min 60\% B; 14 min 100\% B; 18 min 100\% B; 18.1 min 5\% B and 19.5 min 5\% B. The flow rate was $0.4 \mathrm{~mL} / \mathrm{min}$ and column temperature was $45^{\circ} \mathrm{C}$. All the samples were kept at $4{ }^{\circ} \mathrm{C}$ during the analysis. The injection was $10 \mu \mathrm{L}$. Data acquisition was performed in full scan mode ( $\mathrm{m} / \mathrm{z}$ ranges from 70 to 1000) combined with IDA mode. The QCs were injected at regular intervals (every 10 samples) throughout the analytical run to provide a set of data from which repeatability can be assessed.

The acquired LC-MS raw data were analyzed by the progqenesis QI software (Waters Corporation, Milford, USA). The internal standard was used for data QC (reproducibility). Metabolites were identified by progenesis QI (Waters Corporation, Milford, USA) Data Processing Software, based on public databases such as http://www.hmdb.ca/; http://www.lipidmaps.org/ and self-built databases. The positive and negative data were combined to get a combine data which was imported into R ropls package. Principle component analysis (PCA) and (orthogonal) partial least-squares-discriminant analysis (O)PLS-DA were carried out to visualize the metabolic alterations among eperimental groups, after mean centering and Pareto variance (Par) scaling, respectively. The Hotelling's T2 region, shown as an ellipse in score plots of the models, defines the $95 \%$ confidence interval of the modeled variation. Variable importance in the projection (VIP) ranks the overall contribution of each variable to the OPLS-DA model, and those variables with VIP > 1 are considered relevant for group discrimination. The differential metabolites were selected on the basis of the combination of a statistically significant threshold of variable influence on projection (VIP) values obtained from the OPLS-DA model and $p$ values from a two-tailed Student's t test on the normalized peak peak areas, where metabolites with VIP values less than 0.05 were considered as differential metabolites.

\section{Statistical analysis}


Analysis of variance (ANOVA) was computed for statistically significant differences using the statistical package SPSS, version 20.0 (SPSS, Chicago, IL, USA).All data are the means \pm SE of four independent replicates; the mean differences were compared utilizing the LSD's multiple range test $(P<0.05)$.

\section{Results}

\section{Effect of different treatments on wheat growth and Cd accumulation}

From the perspective of growth, the wheat growth under Cd-treated, including $\mathrm{CK}+\mathrm{Cd}, \mathrm{CK}+\mathrm{Cd}+\mathrm{B}$ and PreB $+\mathrm{Cd}$, were significantly weaker than that without Cd-treated (CK and CK + B) (Fig. 1a). Boron (B) application can improve the wheat growth under Cd stress (Fig. 1b). Similar trend was observed in PreB + Cd treatment compared with $\mathrm{CK}+\mathrm{Cd}+\mathrm{B}$ treatment (Fig. 1c). Compared with $\mathrm{CK}+\mathrm{Cd}$, the fresh weight (FW) increased by $15.22 \%$ and $56.52 \%$ in root under $\mathrm{CK}+$ $\mathrm{Cd}+\mathrm{B}$ and PreB $+\mathrm{Cd}$ treatment, where decreased by $10.59 \%$ and $45.88 \%$ in root respectively (Table 1$)$. Cd treatment lead to a dramatic reduction of root and shoot water content, while little effect on water content with B treatment. Compared with CK + Cd, shoot Cd concentrations decreased by $8.78 \%$ and $3.99 \%$ under $\mathrm{CK}+\mathrm{Cd}+\mathrm{B}$ and PreB $+\mathrm{Cd}$ treatment, where root $\mathrm{Cd}$ concentrations decreased by 26.34 and $26.30 \%$, respectively. However, the transport coefficients of Cd transport from roots to shoots increased $10.57 \%$ and $35.07 \%$ under $\mathrm{CK}+\mathrm{Cd}+\mathrm{B}$ and PreB $+\mathrm{Cd}$ treatment compared with $\mathrm{CK}+\mathrm{Cd}$ treatment. These results suggest that $\mathrm{B}$ can inhibit the absorption of $\mathrm{Cd}$ and promote plant growth, and B pretreatment is more effective in alleviating Cd-inhibited wheat.

Table 1

Biomass, water content and Cd concentration in tissues of wheat

\begin{tabular}{|c|c|c|c|c|c|}
\hline & CK & $\mathrm{CK}+\mathrm{B}$ & $\mathrm{CK}+\mathrm{Cd}$ & $C K+C d+B$ & PreB + Cd \\
\hline Shoot FW (g plant ${ }^{-1}$ ) & $1.57 \pm 0.11 a b$ & $1.82 \pm 0.04 a$ & $0.85 \pm 0.01 c$ & $0.94 \pm 0.16 c$ & $1.24 \pm 0.14 b c$ \\
\hline Root FW (g plant ${ }^{-1}$ ) & $0.81 \pm 0.09 a b$ & $1.03 \pm 0.03 a$ & $0.46 \pm 0.05 c$ & $0.53 \pm 0.11 b c$ & $0.72 \pm 0.06 \mathrm{abc}$ \\
\hline Shoot water content (\%) & $92.55 \pm 0.54 a b$ & $93.34 \pm 0.10 a$ & $91.18 \pm 0.53 a b c$ & $89.94 \pm 0.73 c$ & $91.44 \pm 0.51 \mathrm{abc}$ \\
\hline Root water content (\%) & $88.54 \pm 0.27 a$ & $88.70 \pm 0.23 a$ & $85.99 \pm 0.55 b$ & $85.17 \pm 0.19 b$ & $86.06 \pm 0.34 b$ \\
\hline Shoot $\mathrm{Cd}$ concentration $\left(\mathrm{mg} \mathrm{kg}^{-1}\right)$ & nd & nd & $225.8 \pm 12.8 a$ & $206.0 \pm 11.7 a$ & $216.8 \pm 12.6 a$ \\
\hline Root Cd concentration $\left(\mathrm{mg} \mathrm{kg}^{-1}\right)$ & nd & nd & $1216.5 \pm 73.1 \mathrm{a}$ & $896.1 \pm 71.2 b$ & $896.6 \pm 35.9 b$ \\
\hline Transport coefficient & - & - & $20.16 \pm 1.20 b$ & $22.29 \pm 0.3 a b$ & $27.23 \pm 2.08 a$ \\
\hline
\end{tabular}

Effect of different treatments on MDA concentration and antioxidant enzymes activities

Lipid peroxidation measured in terms of MDA increased in all the Cd stressed plants comparing with control. Compared with CK treatment, MDA concentration significant increased with $120.8 \%, 62.00 \%$ and $122.68 \%$ in root, and $188.86 \%, 122.25 \%$ and $221.72 \%$ in shoot at CK $+C d, C K+C d+B$ and PreB $+C d$ treatments respectively (Fig. 2). The MDA concentration decreased $26.62 \%(P<0.05)$ in root and $23.06 \%$ in shoot respectively under $\mathrm{CK}+\mathrm{Cd}+\mathrm{B}$ treatment compared with $\mathrm{CK}+\mathrm{Cd}$ treatment. However, the MDA concentrations have no significantly difference between PreB $+\mathrm{Cd}$ treatment and $\mathrm{CK}+\mathrm{Cd}$ treatment.

In the present study, the key enzymes including SOD, POD and CAT exhibited differential responses to Cd treatments in shoots and roots of wheat (Fig. 3). It was found that SOD activity significant increased by $84.11 \%, 54.19 \%$ and $48.44 \%$ at CK + Cd, CK + Cd + B and PreB + Cd compared with CK in root respectively(Fig. 3a), while no significant differences in shoot (Fig. 3b). Compared with $\mathrm{CK}+\mathrm{Cd}$ treatment, SOD activity significant decreased by $16.25 \%$ and $19.37 \%$ at CK + Cd + B and PreB + Cd, respectively. Similarly, POD activity under Cd-treatment showed an increased tendency, especially increased by $359.52 \%$, $300.49 \%$ and $366.21 \%$ at $C K+C d, C K+C d+B$ and PreB $+C d$ compared with CK in shoot (Fig. 3d). However, there was no significant difference in POD activity between $\mathrm{CK}+\mathrm{Cd}+\mathrm{B}$ and PreB $+\mathrm{Cd}$ compared with $\mathrm{CK}+\mathrm{Cd}$. Different from SOD and POD, CAT activity of the Cd-treated plants was decreased compared with the CK in both shoot and root (Fig. 3e and f). Especially at the root, lower activity of CAT was observed where $29.58 \%, 51.58 \%$ and $79.81 \%$ decreased respectively at $\mathrm{CK}+\mathrm{Cd}, \mathrm{CK}+\mathrm{Cd}+\mathrm{B}$ and $\mathrm{PreB}+\mathrm{Cd}$ compared with $\mathrm{CK}$. In addition, the CAT activity decreased $31.24 \%$ and $71.33 \%$ in root at $\mathrm{CK}+\mathrm{Cd}+\mathrm{B}$ and PreB + Cd compared with $\mathrm{CK}+\mathrm{Cd}$.

\section{Effect of different treatments on root extract metabolite}

To better explore the differential metabolites in B alleviates the $\mathrm{Cd}$ toxicity metabolites, the differential metabolites of wheat under $\mathrm{CK}$, CK $+\mathrm{Cd}$ and $\mathrm{CK}+\mathrm{Cd}+\mathrm{B}$ were analyzed by LC-MS. Our data show that the parameters of the OPLS-DA for the classification were expressed by the R2Y (cum) of 0.866 and Q2 (cum) of 0.368 for $\mathrm{CK}+\mathrm{B}$ and CK treatment (Fig. 4a), 0.983 and 0.941 for CK + Cd and CK treatment (Fig. 4b), 0.81 and 0.0107 for CK + Cd + B and CK + B treatment (Fig. 4C), respectively. In addition, methods of 7-fold cross validation and response permutation testing (RPT) were used to investigate the quality of the model, indicating that there was no overfitting in the measurement model. These parameters representing the exhibited a better stability and predictability, and effectively reflected the metabolic differences between treatment.

The Volcano plot were used to visualize the $P$ value and the fold change value to screen the differential metabolites under positive ion mode and negative ion mode. As shown in the Fig. 4, the red origin represents the significantly up-regulated differential metabolites in the experimental group, the blue origin represents the significantly down-regulated differential metabolites, and the gray point represents the non-significantly different metabolites. Using VIP screening (variable importance in the projection) $>1$ at a level of $P<0.05$, a total of 198 of the differential metabolites were isolated between CK $+\mathrm{B}$ and $\mathrm{CK}$ 
treatment, in which a total of 91 of the differential metabolites were up-regulated (red dots, Fig. $4 \mathrm{~d}$ ) and a total of 107 of the differential metabolites were down-regulated (blue dots, Fig. 4d) in the CK + B treatment compared with CK treatment, respectively. In the same way, a total of 680 of the differential metabolites were isolated between CK $+\mathrm{Cd}$ and CK treatment, in which a total of 341 of the differential metabolites were up-regulated (red dots, Fig. $4 \mathrm{e}$ ) and a total of 339 of the differential metabolites were down-regulated (blue dots, Fig. $4 \mathrm{e}$ ) in the $\mathrm{CK}+\mathrm{Cd}$ treatment compared with CK treatment, respectively. A total of 204 of the differential metabolites were isolated between $\mathrm{CK}+\mathrm{Cd}+\mathrm{B}$ and $\mathrm{CK}+\mathrm{Cd}$ treatment, in which a total of 132 of the differential metabolites were upregulated (red dots, Fig. 4f) and a total of 72 of the differential metabolites were down-regulated (blue dots, Fig. $4 \mathrm{f}$ ) in the $\mathrm{CK}+\mathrm{Cd}+\mathrm{B}$ treatment compared with $\mathrm{CK}+\mathrm{Cd}$ treatment, respectively. Furthermore, using screening conditions with more than 1 of VIP and fold change at a level of $P$ less than 0.05 , we isolated out a total of top 50 of the differential metabolites as show in Table 2 . Analyses show that the B application (CK $+C d+B)$ not only obviously up-regulated accumulation of galactaric acid, citric acid, N6-Galacturonyl-L-lysine, D-Glucose, 3,4,5-trihydroxy-6-\{[4-methoxy-6-(3-oxoprop-1-en-1-yl)-2H-1,3-benzodioxol-5yl]oxy\}oxane-2-carboxylic acid, N-Acetyldjenkolic acid, and 2-Methylthiophene, but also down-regulated the accumulation of threoninyl-tryptophan and C16 sphinganine in the roots compared with $\mathrm{CK}+\mathrm{Cd}(\mathrm{VIP}>5)$. 
Table 2

Identification of metabolites (Top 50) under different treatments

\begin{tabular}{|c|c|c|c|c|c|c|}
\hline \multirow[t]{2}{*}{ Metabolites } & \multicolumn{2}{|c|}{$\mathrm{Ck}+\mathrm{B}$ vs CK } & \multirow[t]{2}{*}{ Metabolites } & \multicolumn{2}{|c|}{$\mathrm{Ck}+\mathrm{Cd}$ vs CK } & \multirow[t]{2}{*}{ Metabolites } \\
\hline & VIP & $\log _{2}(\mathrm{FC})$ & & VIP & $\log _{2}(\mathrm{FC})$ & \\
\hline Glucocerebrosides & 9.05 & 0.64 & p-Coumaroylputrescine & 32.95 & 1.98 & Galactaric acid \\
\hline Cer(d18:0/15:0) & 8.10 & 0.89 & Rutalinium & 25.77 & 2.65 & Citric acid \\
\hline $\mathrm{PI}(20: 1(11 Z) / 22: 2(13 Z, 16 Z))$ & 7.90 & 0.35 & $\begin{array}{l}\text { 4-Coumaroyl-2- } \\
\text { hydroxyputrescine }\end{array}$ & 21.72 & 3.97 & N6-Galacturonyl-L-lysine \\
\hline $\mathrm{N}$-stearoyl alanine & 7.25 & 0.23 & Threoninyl-Tryptophan & 10.28 & 6.26 & D-Glucose \\
\hline Drotaverine & 5.98 & 3.41 & Ribalinium & 9.70 & 3.30 & $\begin{array}{l}\text { 3,4,5-trihydroxy-6-\{[4- } \\
\text { methoxy-6-(3-oxoprop-1-er } \\
1-y \mid)-2 H-1,3-\text {-benzodioxol-5 } \\
\text { ylloxy\}oxane-2-carboxylic } \\
\text { acid }\end{array}$ \\
\hline GlcCer(d18:2(4E,8Z)/16:0(2OH[R])) & 5.83 & 0.52 & N1-trans-Feruloylagmatine & 7.80 & 5.24 & N-Acetyldjenkolic acid \\
\hline Cer(d16:1/17:0) & 5.42 & 0.87 & Beta-D-Glucopyranuronic acid & 7.64 & 1.25 & 2-Methylthiophene \\
\hline Glyuranolide & 4.98 & 0.31 & $\begin{array}{l}\text { 1-(m- } \\
\text { Methoxycinnamoyl)pyrrolidine }\end{array}$ & 7.16 & 1.68 & Diferuloylputrescine \\
\hline DG(18:4(6Z,9Z,12Z,15Z)/24:1(15Z)/0:0) & 4.37 & 1.43 & $\begin{array}{l}\text { N,N'-Bis(gamma- } \\
\text { glutamyl)cystine }\end{array}$ & 6.03 & 5.41 & $\mathrm{PI}(20: 1(11 \mathrm{Z}) / 22: 2(13 \mathrm{Z}, 16$ \\
\hline $\begin{array}{l}\text { 1a-hydroxy-26,27-dimethylvitamin D3 / 1a- } \\
\text { hydroxy-26,27-dimethylcholecalciferol }\end{array}$ & 4.00 & 0.82 & Cefuroxime & 5.96 & 0.44 & $\begin{array}{l}\text { 9S-hydroxy-10S,11S-epox) } \\
\text { 12Z,15Z-octadecadienoic } \\
\text { acid }\end{array}$ \\
\hline TG(14:0/18:1(11Z)/o-18:0) & 3.56 & 0.36 & $\begin{array}{l}\text { 6-[3-(6,7-dimethoxy-2H-1,3- } \\
\text { benzodioxol-5-yl)oxirane-2- } \\
\text { carbonyloxy]-3,4,5- } \\
\text { trihydroxyoxane-2-carboxylic } \\
\text { acid }\end{array}$ & 5.72 & 5.50 & $\begin{array}{l}\text { 4-O-Caffeoyl-3-0- } \\
\text { feruloylquinic acid }\end{array}$ \\
\hline N-Oleoyl-D-erythro-Sphingosine (C18:1 Ceramide) & 3.46 & 1.08 & $\begin{array}{l}\text { Acacetin 7-(4"'"- } \\
\text { Acetylrhamnosyl)-(1->6)- } \\
\text { glucosyl-(1->3)-(6"-- } \\
\text { acetylglucoside) }\end{array}$ & 5.67 & 2.20 & D-Myoinositol 4-phosphatı \\
\hline $\mathrm{PC}(20: 0 / \mathrm{P}-18: 0)$ & 3.35 & 0.22 & Coumarin & 5.19 & 1.88 & $\begin{array}{l}\text { 12,13-Epoxy-9,15- } \\
\text { octadecadienoic acid }\end{array}$ \\
\hline $\mathrm{PE}(14: 1(9 Z) / 15: 0)$ & 3.15 & 0.51 & Cefpodoxime & 4.78 & 5.42 & 2-Hydroxyadipic acid \\
\hline PE-GIcGIcDG(P-14:0/16:1(9Z)) & 2.78 & 0.30 & Safynol & 4.64 & 2.02 & 4R-aminopentanoic acid \\
\hline Vinaginsenoside R14 & 2.64 & 2.09 & $\begin{array}{l}\text { Phenylacetylglycine } \\
\text { dimethylamide }\end{array}$ & 4.43 & 2.24 & Desglucocoroloside \\
\hline Cer(d18:1/17:0) & 2.57 & 1.27 & $\begin{array}{l}\text { Methyl 2-(10-heptadecenyl)-6- } \\
\text { hydroxybenzoate }\end{array}$ & 3.98 & 1.40 & $\begin{array}{l}\text { 3,4-dimethyl-5-propyl-2- } \\
\text { furanoctanoic acid; }\end{array}$ \\
\hline Cer(d18:0/14:0) & 2.50 & 0.79 & Embinin & 3.68 & 1.98 & $\begin{array}{l}\text { 3-methyl-5-pentyl-2- } \\
\text { furanoctanoic acid }\end{array}$ \\
\hline DG(20:0/0:0/18:2n6) & 2.48 & 1.25 & $\mathrm{~N}$-stearoyl valine & 21.62 & -0.37 & $\begin{array}{l}\text { 13R,23S- } \\
\text { Dimethylpentatriacontane }\end{array}$ \\
\hline 13R-HOME(11E) & 2.47 & 0.37 & 9,10,13-TriHOME & 16.02 & -1.58 & $\begin{array}{l}\text { 3-methoxy Prostaglandin } \\
\text { F1a }\end{array}$ \\
\hline PS(18:4(6Z,9Z,12Z,15Z)/20:5(5Z,8Z,11Z,14Z,17Z)) & 2.44 & 7.85 & Azelaic acid & 11.12 & -1.12 & $\begin{array}{l}\text { beta-D-Xylopyranosyl-(1->! } \\
\text { alpha-L-arabinofuranosyl- } \\
>5 \text {-L-arabinose }\end{array}$ \\
\hline 2-hydroxyhexadecanoic acid & 2.43 & 0.20 & $\begin{array}{l}\text { 12,13,15-trihydroxy-9E- } \\
\text { octadecenoic acid }\end{array}$ & 10.81 & -1.71 & $\begin{array}{l}\text { Prostaglandin PGE2 1- } \\
\text { glyceryl ester }\end{array}$ \\
\hline Densipolic acid & 2.36 & 2.27 & Porson & 10.58 & -0.67 & Aspartyl-Cysteine \\
\hline Notoginsenoside $\mathrm{H}$ & 2.32 & 2.55 & Citric acid & 10.11 & -1.87 & (-)-Enunicelline \\
\hline $\begin{array}{l}\text { N-(2R-Hydroxyhexadecanoyl)-2S-amino-9-methyl- } \\
\text { 4E,8E-octadecadiene-1,3R-diol }\end{array}$ & 2.31 & 0.96 & $\mathrm{PI}(0-16: 0 / 15: 1(9 \mathrm{Z}))$ & 9.05 & -0.23 & 12-amino-octadecanoic ac \\
\hline
\end{tabular}

Note: VIP indicates the weight value of the variable from the OPLS-DA model. Generally, the metabolites of VIP $>1$ are considered as differential metabolites. the greater the contribution of the variable to the grouping. FC: fold change. $\log _{2}(\mathrm{FC})$ : the ratio of the average expression of metabolites in the two groups of : means up-regulation, negative value means down-regulation. 


\begin{tabular}{|c|c|c|c|c|c|c|}
\hline \multirow[t]{2}{*}{ Metabolites } & \multicolumn{2}{|c|}{ Ck+B vs CK } & \multirow[t]{2}{*}{ Metabolites } & \multicolumn{2}{|c|}{ Ck+ Cd vs CK } & \multirow[t]{2}{*}{ Metabolites } \\
\hline & VIP & $\log _{2}(\mathrm{FC})$ & & VIP & $\log _{2}(\mathrm{FC})$ & \\
\hline 9-oxo-9,11-seco-campest-5-en-3beta,11-diol & 2.26 & 0.75 & Galactaric acid & 8.78 & -2.00 & $\begin{array}{l}\text { 2-deoxy-20- } \\
\text { hydroxyecdysone 22- } \\
\text { phosphate }\end{array}$ \\
\hline p-Coumaroylputrescine & 23.74 & -0.58 & 9,10-DHOME & 7.65 & -1.38 & N2-Acetyl-L-aminoadipate \\
\hline Galactaric acid & 12.60 & -0.83 & $\begin{array}{l}\{[3-(2 \text {-hydroxyphenyl)prop-2- } \\
\text { en-1-yl]oxy\}sulfonic acid }\end{array}$ & 7.36 & -3.58 & Monic acid \\
\hline N-palmitoyl alanine & 7.37 & -0.19 & $\mathrm{~N}$-palmitoyl alanine & 6.99 & -0.55 & $\begin{array}{l}\text { 20-hydroxyecdysone 22- } \\
\text { phosphate }\end{array}$ \\
\hline 1-(m-Methoxycinnamoyl)pyrrolidine & 6.70 & -0.71 & Margaroylglycine & 5.66 & -0.65 & $( \pm) 12(13)$-EpOME \\
\hline $\begin{array}{l}\text { 1alpha,25-dihydroxy-23-azavitamin D3 / } \\
\text { 1alpha,25-dihydroxy-23-azacholecalciferol }\end{array}$ & 6.60 & -2.75 & $\begin{array}{l}\text { 9S-hydroxy-10S,11S-epoxy- } \\
\text { 12Z,15Z-octadecadienoic acid }\end{array}$ & 5.48 & -1.30 & N-Gluconyl ethanolamine \\
\hline D-Glucose & 5.94 & -0.48 & 9,10,18-TriHOME(12) & 5.42 & -1.36 & Camellenodiol \\
\hline Acetylcholine & 5.68 & -1.34 & $\begin{array}{l}\text { 12-hydroxy-8E,10E- } \\
\text { heptadecadienoic acid }\end{array}$ & 5.10 & -0.94 & $\begin{array}{l}\text { 1-(sn-Glycero-3- } \\
\text { phospho)-1D-myo-inositol }\end{array}$ \\
\hline 3-amino-2-naphthoic acid & 5.63 & -0.47 & 12-oxo-PDA & 5.05 & -1.57 & O-Demethylfonsecin \\
\hline N1-(alpha-D-ribosyl)-5,6-dimethyl-benzimidazole & 4.57 & -0.49 & D-Glucose & 4.89 & -1.16 & Avenoleic acid \\
\hline N-Acetyldjenkolic acid & 4.45 & -0.63 & Guanine & 4.80 & -1.20 & 17-hydroxy-linolenic acid \\
\hline Spermic acid 2 & 4.15 & -0.31 & a-9(10)-EpODE & 4.66 & -1.74 & 8,13-DiHODE \\
\hline Eicosanoyl-EA & 3.80 & -0.28 & $( \pm) 13-\mathrm{HpODE}$ & 4.62 & -1.39 & Adenine \\
\hline Coumarin & 3.75 & -0.51 & 3-Deoxyguanosine & 4.57 & -1.62 & Threoninyl-Tryptophan \\
\hline 4R-aminopentanoic acid & 3.73 & -0.87 & 16-L1-PhytoP & 4.39 & -1.28 & C16 Sphinganine \\
\hline Tricosanoylglycine & 3.57 & -0.36 & cis-Hydroxy Perhexiline & 4.36 & -0.66 & 17-hydroxy stearic acid \\
\hline Linoleic acid & 2.97 & -0.23 & 16-F1-PhytoP & 4.35 & -1.03 & TG(14:0/18:1(11Z)/o-18:0 \\
\hline 9S-HpOTrE & 2.95 & -0.58 & 9,12,13-TriHOME & 4.24 & -1.86 & L-Phenylalanine \\
\hline Spermine & 2.95 & -0.56 & Isoleucylproline & 4.08 & -0.60 & Embinin \\
\hline (Z)-4-Hepten-1-ol & 2.85 & -0.44 & N-Hexadecyl-L-hydroxyproline & 4.05 & -0.48 & $\begin{array}{l}\text { 1-Phenyl-1,3- } \\
\text { octadecanedione }\end{array}$ \\
\hline 12-amino-octadecanoic acid & 2.77 & -0.26 & 2-Methylthiophene & 4.03 & -1.30 & Histidinyl-Isoleucine \\
\hline 27-Nor-5b-cholestane-3a,7a,12a,24,25-pentol & 2.71 & -0.34 & 9(S)-HpODE & 3.98 & -1.36 & $\begin{array}{l}\text { 1,N2- } \\
\text { propanodeoxyguanosine }\end{array}$ \\
\hline delta10-13-PhytoF & 2.67 & -0.36 & OKODA-PA & 3.95 & -4.94 & Mizoribine \\
\hline 6-Deoxyfagomine & 2.53 & -1.82 & Lymecycline & 3.78 & -1.82 & Spermic acid 2 \\
\hline Traumatic Acid & 2.28 & -0.46 & OHODA-PA & 3.71 & -4.64 & 20:0 Campesteryl ester \\
\hline
\end{tabular}

Note: VIP indicates the weight value of the variable from the OPLS-DA model. Generally, the metabolites of VIP $>1$ are considered as differential metabolites. the greater the contribution of the variable to the grouping. FC: fold change. $\log _{2}(\mathrm{FC})$ : the ratio of the average expression of metabolites in the two groups of : means up-regulation, negative value means down-regulation.

\section{The pathway enrichment analysis of differential metabolites}

The pathway enrichment analysis of differential metabolites was carried out according to the Kyoto Encyclopedia of Genes and Genomes (KEGG, https://www.kegg.jp/) database. Pathway enrichment analysis show that the differential metabolites (top 50) were involved glycerophospholipid metabolism, linoleic acid metabolism, one carbon pool by folate, glycosylphosphatidylinositol (GPI)-anchor biosynthesis, autophagy-other, pentose phosphate pathway, alpha-Linolenic acid metabolism, galactose metabolism, aminoacyl-tRNA biosynthesis, AGE-RAGE signaling pathway in diabetic complications between CK + B treatment and CK treatment (Fig. 5a); linoleic acid metabolism, pyrimidine metabolism, glycerophospholipid metabolism, purine metabolism, one carbon pool by folate, beta-Alanine metabolism, alpha-Linolenic acid metabolism, cyanoamino acid metabolism, aminoacyl-tRNA biosynthesis, sphingolipid metabolism for CK + Cd treatment and CK treatment (Fig. 5b); linoleic acid metabolism, galactose metabolism, sphingolipid metabolism, glycolysis/gluconeogenesis, propanoate metabolism, fructose and mannose metabolism, AGE-RAGE signaling pathway in diabetic complications, pyrimidine metabolism, phenylalanine metabolism, arachidonic acid metabolism for $\mathrm{CK}+\mathrm{Cd}+\mathrm{B}$ treatment and $\mathrm{CK}+\mathrm{B}$ treatment (Fig. $5 \mathrm{c}$ ).

\section{Discussion}


Cadmium (Cd) is a toxic heavy metal that has been known causing many physiological disorders such as a decrease in photosynthesis, sugars and soluble proteins and antioxidant enzyme activities, and also increased the production of reactive oxygen species (ROS) which caused oxidative stress in plants (Abbasi et al. 2015; Chen et al. 2018). This would result in a retardation of plant growth, reduction in biomass and grain yield. Boron (B) is an essential micronutrient for the structural and functional integrity of the cell wall and membranes, photosynthesis, cell division and elongation, nitrogen and carbohydrate metabolism, etc. (Shireen et al. 2018). Meanwhile, studies have also found that B plays a crucial role in alleviated Cd accumulation and toxicity (Chen et al. 2019; Qin et al. 2020b). Here, we determined the responses of wheat against Cd stress under B supply or pre-supply, with respect to their biomass, ROS scavenging mechanism and differential metabolite mechanism.

The present study revealed that Cd application and B deficiency inhibited the growth of wheat, while B supply or pre-supply could improve the wheat growth under $\mathrm{Cd}$ stress. In addition, the root and shoot $\mathrm{Cd}$ concentration were decreased under B supply or pre-supply compared with $\mathrm{CK}+\mathrm{Cd}$ treatment, especially at the root. While the transport coefficients of $\mathrm{Cd}$ transport from roots to shoots increased under $\mathrm{CK}+\mathrm{Cd}+\mathrm{B}$ and PreB $+\mathrm{Cd}$ treatment compared with $\mathrm{CK}+\mathrm{Cd}$ treatment. Similar result were also found in our previous study (Qin et al. 2020b). These results suggest that $B$ can inhibit the absorption of $C d$ and promote its migration from root to aboveground, where B pretreatment is more effective in inhibiting $\mathrm{Cd}$ absorption and promote $\mathrm{Cd}$ migration.

Oxidative stress is inevitably related to $\mathrm{Cd}$ stress in plants and the antioxidant defense machinery protects plants against oxidative stress damages (Gill and Tuteja 2010). For example, malondialdehyde (MDA) represents the degree of lipid peroxidation and reflects the degree of cell damage. Antioxidant enzymes can remove reactive oxygen species (ROS) from plants and reduce the abiotic stress caused by $\mathrm{Cd}$. In our study, MDA concentration significant increase in root and shoot at $\mathrm{CK}+\mathrm{Cd}$ treatment compared with $\mathrm{CK}$ treatment respectively, while the MDA concentration decreased under $\mathrm{CK}+\mathrm{Cd}+\mathrm{B}$ treatment compared with $\mathrm{CK}+\mathrm{Cd}$ treatment. This results indicates that $\mathrm{B}$ could reduce the accumulation of MDA to alleviate Cd toxicity in wheat. In order to better understand the role of $B$ in antioxidant enzymes, the antioxidant enzymes activity of superoxide dismutase (SOD), peroxidase (POD) and catalase (CAT) were detected. SOD is a key enzyme that constitutes the first line of defense against ROS, where converts superoxide radicals into less toxic agents, producing $\mathrm{H}_{2} \mathrm{O}_{2}$ (Gill et al. 2010). CAT and POD are important enzymes that scavenge excess of $\mathrm{H}_{2} \mathrm{O}_{2}$ by catalyzing it into water and divalent oxygen for ROS detoxification (Garg and Manchanda 2009). Here, it was found that SOD and POD activity significant increased at Cd treatment. However, lower SOD and POD activity were found under $\mathrm{CK}+\mathrm{Cd}+\mathrm{B}$ and PreB $+\mathrm{Cd}$ compared with $\mathrm{CK}$ treatment. In addition, lower activity of CAT was also observed at B application compared with Cd treatment in root. The results suggested that SOD and POD activity have been greatly activated under Cd stress condition and almost all the antioxidant enzymes moderately reduced after B application.

Some small molecular compounds play an important role in plant transport heavy metals and resistance to heavy metal stress. For instance, $\mathrm{Zn}$ hyperaccumulation was associated with enhanced xylem transport and phloem remobilization of Zn by bound to organic acid and citric acid in Sedum alfredii (Lu et al. 2013). For Cd, studies show that glutathione (GSH), metallothioneins (MTs), and phytochelatins (PCs) are the most important ligands involved in Cd detoxification in plants (Gallego et al. 2012; Nakamura et al. 2020). In addition, phytosiderophores, organic acids, amino acids, peptides and proteins have also been discovered as important ligands in inducing Cd precipitation by chelation (Bali et al. 2020). Within plant cells, Cd can bind to these small molecule compounds to protect the cytosol from free Cd ions and sequester Cd in the vacuole to increase the tolerance of plants to Cd (Schat et al. 2002 ; Zimeri et al. 2005; Ernst et al. 2008). In the present study, a total of 198, 680 and 204 of the differential metabolites were isolated between CK + B and CK treatment, CK + $\mathrm{Cd}$ and $\mathrm{CK}$ treatment and $\mathrm{CK}+\mathrm{Cd}+\mathrm{B}$ and $\mathrm{CK}+\mathrm{Cd}$ treatment respectively. B application $(\mathrm{CK}+\mathrm{Cd}+\mathrm{B})$ not only obviously up-regulated accumulation of galactaric acid, citric acid, N6-Galacturonyl-L-lysine, D-Glucose, 3,4,5-trihydroxy-6-\{[4-methoxy-6-(3-oxoprop-1-en-1-yl)-2H-1,3-benzodioxol-5-yl]oxy\}oxane-2carboxylic acid, N-Acetyldjenkolic acid, and 2-Methylthiophene, but also down-regulated the accumulation of threoninyl-tryptophan and C16 sphinganine in the roots compared with $\mathrm{CK}+\mathrm{Cd}(\mathrm{VIP}>5)$. Furthemore, differential metabolic pathways were mainly concentrated in linoleic acid metabolism, galactose metabolism, sphingolipid metabolism, glycolysis/gluconeogenesis, propanoate metabolism, fructose and mannose metabolism, AGE-RAGE signaling pathway in diabetic complications between $\mathrm{CK}+\mathrm{Cd}+\mathrm{B}$ treatment and $\mathrm{CK}+\mathrm{B}$ treatment. A previous study has also shown that $\mathrm{B}$ nutrition could change the organic carbon structure of cell walls and enhanced the contents of amino acid, cellulose, phenols and lignin in the cell wall (Dong et al. 2016; Wu et al. 2018). In addition, B nutrition could induce changes in pectin composition and architecture of components in root cell walls, which have been shown to play an important role in inhibiting Cd absorption (Wu et al. 2016; Wu et al. 2017). Therefore, we hypothesize that these differential metabolites, including carbohydrate and amino acid compounds, play a key role in mitigation of Cd toxicity with B application. Nevertheless, other metabolites and metabolic pathways may also be involved in B mitigation of $\mathrm{Cd}$ toxicity in wheat, which still needs further verification.

\section{Conclusions}

In this study, we demonstrated that B application reduces Cd absorption, MDA content and mitigates Cd toxicity in wheat. In addition, the key enzymes activity including SOD and POD significant increased with Cd application, while decreased under B application. The changes observed in metabolites of galactaric acid, citric acid, N6-Galacturonyl-L-lysine, D-Glucose, 3,4,5-trihydroxy-6-\{[4-methoxy-6-(3-oxoprop-1-en-1-yl)-2H-1,3-benzodioxol-5-yl]oxy\}oxane-2-carboxylic acid, $\mathrm{N}$-Acetyldjenkolic acid, 2-Methylthiophene, threoninyl-tryptophan and C16 sphinganine (VIP > 5) involved in linoleic acid metabolism, galactose metabolism, sphingolipid metabolism, glycolysis/gluconeogenesis, propanoate metabolism, fructose and mannose metabolism, AGE-RAGE signaling pathway in diabetic complications of roots in response to B application under $\mathrm{Cd}$ stress. The overall results indicated that B can change antioxidant enzyme activity and small molecule metabolites to affect plant stress to $\mathrm{Cd}$.

\section{Declarations}

\section{Ethics approval and consent to participate}

Not applicable. 


\section{Consent to Publish}

Not applicable.

\section{Authors Contributions}

Shiyu Qin and Peng Zhao conceived and designed the research. Shiyu Qin, Zhaojun Nie, Chang Li and Yafang Xu perform all the experiments, including supervised the study, implemented the method and performed data analysis, interpreted the data and wrote the manuscript. Wei Gao and Hongen Liu supervised the study and checked the results. All authors read and approved the manuscript.

\section{Funding}

This research was funded by the Chinese State Natural Science Foundation (32002128) and the Scientific and Technological Key Projects of Henan Province (212102310979, 202102110213). We thank Shanghai Lu Ming Biotech Co., Ltd. (Shanghai, China) for assistance with LC-MS metabonomics analysis.

\section{Competing Interests}

The authors declare that they have no competing interests.

\section{Availability of data and materials}

All data generated or analysed during this study are included in this published article [and its supplementary information files].

\section{References}

1. Abbasi GH, Akhtar J, Anwar-ul-Haq M, Malik W, Ali S, Chen ZH, Zhang G (2015) Morpho-physiological and micrographic characterization of maize hybrids under $\mathrm{NaCl}$ and Cd stress. Plant Growth Regul 75:115-122. https://doi.rog/10.1007/s10725-014-9936-6

2. Astolfi S, Zuchi S, Neumann G, Cesco S, Sanità di Toppi L, Pinton R (2012) Response of barley plants to Fe deficiency and Cd contamination as affected by S starvation. J Exp Bot 63:1241-1250. https://doi.rog/10.1093/jxb/err344

3. Bali AS, Sidhu GPS, Kumar V (2020) Root exudates ameliorate cadmium tolerance in plants: A review. Environ Chem Lett 18:1243-1275. https://doi.rog/10.1007/s10311-020-01012-x

4. Bellaloui N (2012) Phomopsis seed infection effects on soybean seed phenol, lignin, and isoflavones in maturity group $V$ genotypes differing in phomopsis resistance. J Crop Improv 26:693-710. https://doi.rog/10.1080/15427528.2012.671236

5. Chen D, Chen D, Xue R, Long J, Lin X, Lin Y, Jia L, Zeng R, Song Y (2019) Effects of boron, silicon and their interactions on cadmium accumulation and toxicity in rice plants. J Hazard Mater 367:447-455. https://doi.rog/10.1016/j.jhazmat.2018.12.111

6. Chen Q, Lu X, Guo X, Pan Y, Yu B, Tang Z, Guo Q (2018) Differential responses to Cd stress induced by exogenous application of Cu, Zn or Ca in the medicinal plant Catharanthus roseus. Ecotoxicol Environ Saf 157:266-275. https://doi.rog/10.1016/j.ecoenv.2018.03.055

7. Clemens S, Aarts MG, Thomine S, Verbruggen N (2013) Plant science: the key to preventing slow cadmium poisoning. Trends Plant Sci 18:92-99. https://doi.rog/10.1016/j.tplants.2012.08.003

8. Dong XC, Liu GD, Wu XW, Lu XP, Muhammad R, Yan L, Muhammad R, Shah A, Wu L, Jiang CC (2016) Different metabolite profile and metabolic pathway with leaves and roots in response to boron deficiency at the initial stage of citrus rootstock growth. Plant Physiol Biochem 108:121-131. https://doi.rog/10.1016/j.plaphy.2016.07.007

9. Duan MM, Wang S, Huang DY, Zhu QH, Liu SL, Zhang Q, Zhu HH, Xu C (2018) Effectiveness of simultaneous applications of lime and zinc/iron foliar sprays to minimize cadmium accumulation in rice. Ecotoxicol Environ Saf 165:510-515. https://doi.rog/10.1016/j.ecoenv.2018.09.037

10. Ernst WHO, Krauss GJ, Verkleij JAC, Wesenberg D (2008) Interaction of heavy metals with the sulphur metabolism in angiosperms from an ecological point of view. Plant Cell Environ 31:123-143. https://doi.rog/10.1111/j.1365-3040.2007.01746.x

11. Fahad S, Hussain S, Khan F, Wu C, Saud S, Hassan S, Ahmad N, Gang D, Ullah A, Huang J (2015) Effects of tire rubber ash and zinc sulfate on crop productivity and cadmium accumulation in five rice cultivars under field conditions. Environ Sci Pollut Res 22:12424-12434. https://doi.rog/10.1007/s11356-015-4518-3

12. Feki-Tounsi M, Hamza-Chaffai A (2014) Cadmium as a possible cause of bladder cancer: a review of accumulated evidence. Environ Sci Pollut Res Int 21:10561-10573. https://doi.rog/10.1007/s11356-014-2970-0

13. Gallego SM, Pena LB, Barcia RA, Azpilicueta CE, lannone MF, Rosales EP, Zawoznika MS, Groppa MD, Benavides MP (2012) Unravelling cadmium toxicity and tolerance in plants: Insight into regulatory mechanisms. Environ Exp Bot 83:33-46. https://doi.rog/10.1016/j.envexpbot.2012.04.006

14. Garg N, Manchanda G (2009) ROS generation in plants: boon or bane? Plant Biosys 143:81-96. https://doi.rog/10.1080/11263500802633626

15. Giannopolitis CN, Ries SK (1977) Superoxide dismutase: 1. Occurrence in higher plants. Plant Physiol 59:309-314. https://doi.rog/10.1104/pp.59.2.309

16. Gill SS, Tuteja N (2010) Reactive oxygen species and antioxidant machinery in abiotic stress tolerance in crop plants. Plant Physiol Biochem 48:909-930. https://doi.rog/10.1016/j.plaphy.2010.08.016

17. He P, Lu Y, Liang Y, Chen B, Wu M, Li S, He G, Jin T (2013) Exposure assessment of dietary cadmium: findings from Shanghainese over 40 years, China. BMC Public Health 13:590. https://doi.rog/10.1186/1471-2458-13-590 
18. Hseu Z, Su S, Lai H, Guo H, Chen T, Chen Z (2010) Remediation techniques and heavy metal uptake by different rice varieties in metal-contaminated soils of Taiwan: new aspects for food safety regulation and sustainable agriculture. Soil Sci Plant Nutr 56:31-52. https://doi.rog/10.1111/j.1747-

0765.2009.00442.x

19. Hu Y, Norton GJ, Duan G, Huang Y, Liu Y (2014) Effect of selenium fertilization on the accumulation of cadmium and lead in rice plants. Plant Soil 384 : 131-140. https://doi.rog/ 10.1007/s11104-014-2189-3

20. Jasinski M, Ducos E, Martinoia E, Bountry M (2003) The ATP-binding cassette transporters: structure, function, and gene family comparison between rice and Arabidopsis. Plant Physiol 131:1169-1177. https://doi.rog/10.1104/pp.102.014720

21. Li X, Li Y, Mai J, Tao L, Qu M, Liu J, Shen R, Xu G, Feng Y, Xiao H, Wu L, Shi L, Guo S, Liang J, Zhu Y, He Y, Baluška F, Shabala S, Yu M (2018) Boron alleviates aluminum toxicity by promoting root alkalization in transition zone via polar auxin transport. Plant Physiol 177:1254-1266. https://doi.rog/10.1104/pp.18.00188

22. Lin L, Zhou W, Dai H, Cao F, Zhang G, Wu F (2012) Selenium reduces cadmium uptake and mitigates cadmium toxicity in rice. J Hazard Mater 235236:343-351. https://doi.rog/10.1016/j.jhazmat.2012.08.012

23. Lu L, Tian S, Zhang J, Yang X, Labavitch JM, Webb SM, Latimer M, Brown PH (2013) Efficient xylem transport and phloem remobilization of Zn in the hyperaccumulator plant species Sedum alfredii. New Phytol 198:721-731. https://doi.rog/10.1111/nph.12168

24. Ma J, Cai H, He C, Zhang W, Wang L (2015) A hemicellulose-bound form of silicon inhibits cadmium ion uptake in rice (Oryza sativa) cells. New Phytol 206:1063-1074. https://doi.rog/10.1111/nph.13276

25. Ma JF, Shen RF, Shao JF (2021) Transport of cadmium from soil to grain in cereal crops: A review. Pedosphere 31(1):3-10. https://doi.rog/10.1016/S1002-0160(20)60015-7

26. Meda AR, Scheuermann EB, PrechsI UE, Erenoglu B, Schaaf G, Hayen H, Weber G, von Wiren N (2007) Iron acquisition by phytosiderophores contributes to cadmium tolerance. Plant Physiol 143:1761-1773. https://doi.rog/10.1104/pp.106.094474

27. Molins H, Michelet L, Lanquar V, Agorio A, Giraudat J, Roach T, Krieger-Liszkay A, Thomine S (2013) Mutants impaired in vacuolar metal mobilization identify chloroplasts as a target for cadmium hypersensitivity in Arabidopsis thaliana. Plant Cell Environ 36(4):804-817.

https://doi.rog/10.1111/pce.12016

28. Nakamura S, Suzuic N, Yin Y, Ishii S, Fujimaki S, Kawachi N, Rai H, Matsumoto T, Sato-Izawa K, Ohkama-Ohtsu N (2020) Effects of enhancing endogenous and exogenous glutathione in roots on cadmium movement in Arabidopsis thaliana. Plant Sci 290:110304. https://doi.rog/10.1016/j.plantsci.2019.110304

29. Qin S, Liu H, Nie Z, Gao W, Li C, Lin Y, Zhao P (2018) AsA-GSH cycle and antioxidant enzymes play important roles in Cd tolerance of wheat. Bull Environ Contam Toxicol 101:684-690. https://doi.rog/10.1007/s00128-018-2471-9

30. Qin S, Liu H, Nie Z, Rengel Z, Gao W, Li C, Zhao P (2020a) Toxicity of cadmium and its competition with mineral nutrients for uptake by plants: A review. Pedosphere 30(2):168-180. https://doi.rog/10.1016/S1002-0160(20)60002-9

31. Qin S, Liu H, Rengel Z, Gao W, Nie Z, Li C, Hou M, Cheng J, Zhao P (2020b) Boron inhibits cadmium uptake in wheat (Triticum aestivum) by regulating gene expression. Plant Sci 297:110522. https://doi.rog/10.1016/j.plantsci.2020.110522

32. Qin X, Nie Z, Liu H, Zhao P, Qin S, Shi Z (2018) Influence of selenium on root morphology and photosynthetic characteristics of winter wheat under cadmium stress. Environ Exp Bot 150:232-239. https://doi.rog/10.1016/j.envexpbot.2018.03.024

33. Ramtahal G, Umaharan P, Hanuman A, Davis C, Ali L (2019) The effectiveness of soil amendments, biochar and lime, in mitigating cadmium bioaccumulation in Theobroma cacao L. Sci Total Environ 693:133563. https://doi.rog/10.1016/j.scitotenv.2019.07.369

34. Rizwan M, Ali S, Abbas T, Zia-Ur-Rehman M, Hannan F, Keller C, Al-Wabel MI, Ok YS (2016) Cadmium minimization in wheat: A critical review. Ecotoxicol Environ Saf 130:43-53. https://doi.rog/10.1016/j.ecoenv.2016.04.001

35. Schat H, Llugany M, Vooijs R, Hartley-Whitaker J, Bleeker PM (2002) The role of phytochelatins in constitutive and adaptive heavy metal tolerance in hyperaccumulator and non-hyperaccumulator metallophytes. J Exp Bot 53:2381-2392. https://doi.rog/10.1093/jxb/erf107

36. Semane B, Cuypers A, Smeets K, Van Belleghem F, Horemans N, Schat H, Vangronsveld J (2007) Cadmium responses in Arabidopsis thaliana: glutathione metabolism and antioxidative defence system. Physiol Plant 129:519-528. https://doi.rog/10.1111/j.1399-3054.2006.00822.x

37. Shireen F, Nawaz MA, Chen C, Zhang Q, Zheng Z, Sohail H, Sun JY, Cao HS, Huang Y, Bie Z (2018) Boron: functions and approaches to enhance its availability in plants for sustainable agriculture. Int J Mol Sci 19:1856. https://doi.rog/10.3390/ijms19071856

38. Uraguchi S, Fujiwara T (2012) Cadmium transport and tolerance in rice: perspectives for reducing grain cadmium accumulation. Rice 5:1-8. https://doi.rog/10.1186/1939-8433-5-5

39. Wang S, Wang F, Gao S (2015) Foliar application with nano-silicon alleviates Cd toxicity in rice seedlings. Environ Sci Pollut Res 22:2837-2845. https://doi.rog/10.1007/s11356-014-3525-0

40. Wang MY, Chen AK, Wong MH, Qiu L, Cheng H, Ye ZH (2011) Cadmium accumulation in and tolerance of rice (Oryza sativa L.) varieties with different rates of radial oxygen loss. Environ Pollut 159:1730-1736. https://doi.rog/10.1016/j.envpol.2011.02.025

41. Wu X, Liu G, Riaz M, Yan L, Jiang C (2018) Metabolic changes in roots of trifoliate orange [Poncirus trifoliate (L.) Raf.] as induced by different treatments of boron deficiency and resupply. Plant Soil 434:217-229. https://doi.rog/10.1007/s11104-018-3684-8

42. Wu X, Riaz M, Yan L, Du C, Liu Y, Jiang C (2017) Boron deficiency in Trifoliate orange induces changes in pectin composition and architecture of components in root cell walls. Front Plant Sci 8:1882. https://doi.rog/10.3389/fpls.2017.01882

43. Wu Z, Liu S, Zhao J, Wang F, Du Y, Zou S, Li H, Wen D, Huang Y (2017) Comparative responses to silicon and selenium in relation to antioxidant enzyme system and the glutathione-ascorbate cycle in flowering Chinese cabbage (Brassica campestris L. ssp. chinensis var. utilis) under cadmium stress.

Page $10 / 13$ 
Environ Exp Bot 133:1-11. https://doi.rog/10.1016/j.envexpbot.2016.09.005

44. Wu Z, Wang F, Liu S, Du Y, Li F, Du R, Wen D, Zhao J (2016) Comparative responses to silicon and selenium in relation to cadmium uptake, compartmentation in roots, and xylem transport in flowering Chinese cabbage (Brassica campestris L. ssp. chinensis var. utilis) under cadmium stress. Environ Exp Bot 131:173-180. https://doi.rog/10.1016/j.envexpbot.2016.07.012

45. Zhang M, Hu C, Zhao X, Tan Q, Sun X, Cao A, Cui M, Zhang Y (2012) Molybdenum improves antioxidant and osmotic-adjustment ability against salt stress in Chinese cabbage (Brassica campestris L. ssp. Pekinensis) Plant Soil 355:375-383. https://doi.rog/10.1007/s11104-011-1109-z

46. Zimeri AM, Dhankher OP, Mccaig B, Meagher RB (2005) The plant MT1 metallothioneins are stabilized by binding cadmiums and are required for cadmium tolerance and accumulation. Plant Mol Biol 58(6):839-855. https://doi.rog/10.1007/s11103-005-8268-3

\section{Figures}

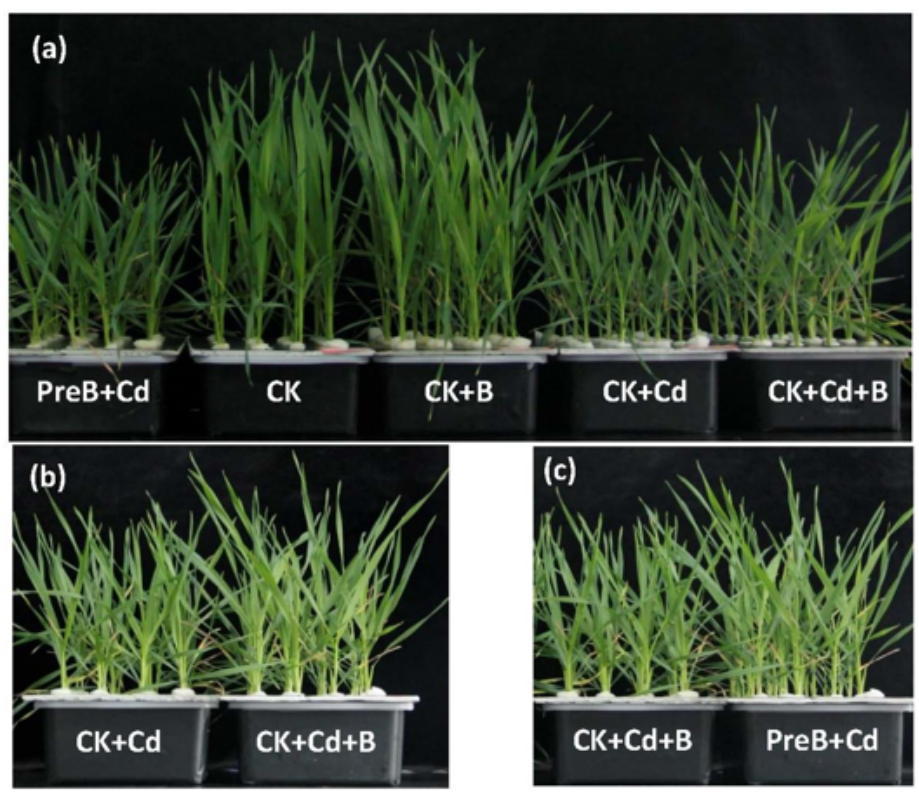

Figure 1

The growing conditions for (a) all treatment, (b) $C K+C d$ and $C K+C d+B$ and (c) PreB+Cd and $C K+C d+B$.
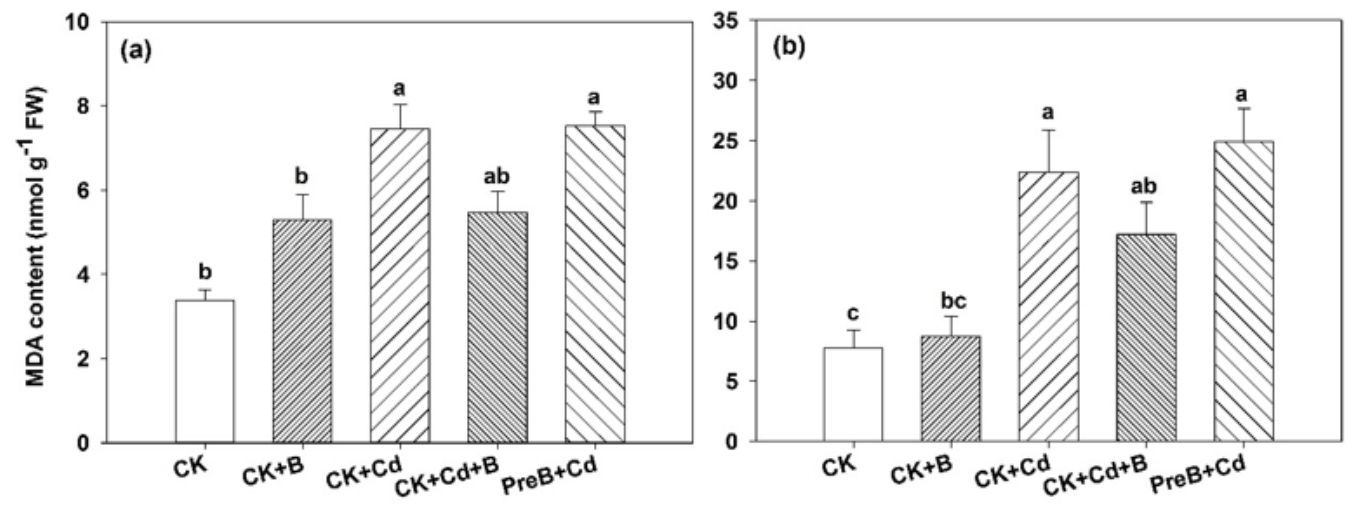

Figure 2

The MDA concentration of root (a) and shoot (b) of wheat under different treatment. Data are means \pm SE. Bar with different letters are significantly different at $\mathrm{P}<0.05$ in multiple comparison by LSD's test. 

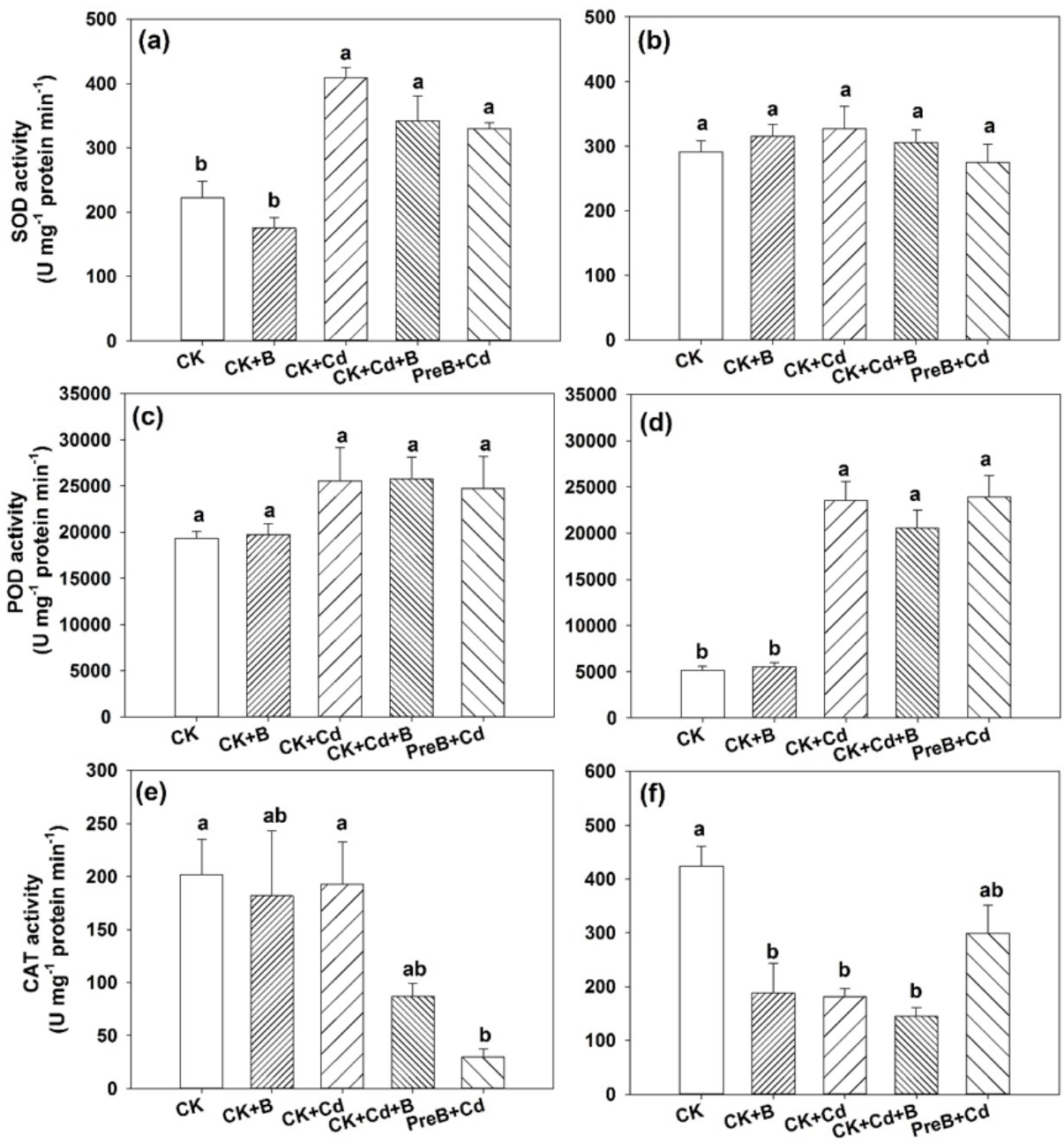

\section{Figure 3}

Superoxide dismutase (SOD) (a and b), peroxidases (POX) (c and d) and catalase (CAT) (e and f) activity in root and shoot respectively under different treatments. Data are means \pm SE. Bar with different letters are significantly different at $P<0.05$ in multiple comparison by LSD's test.
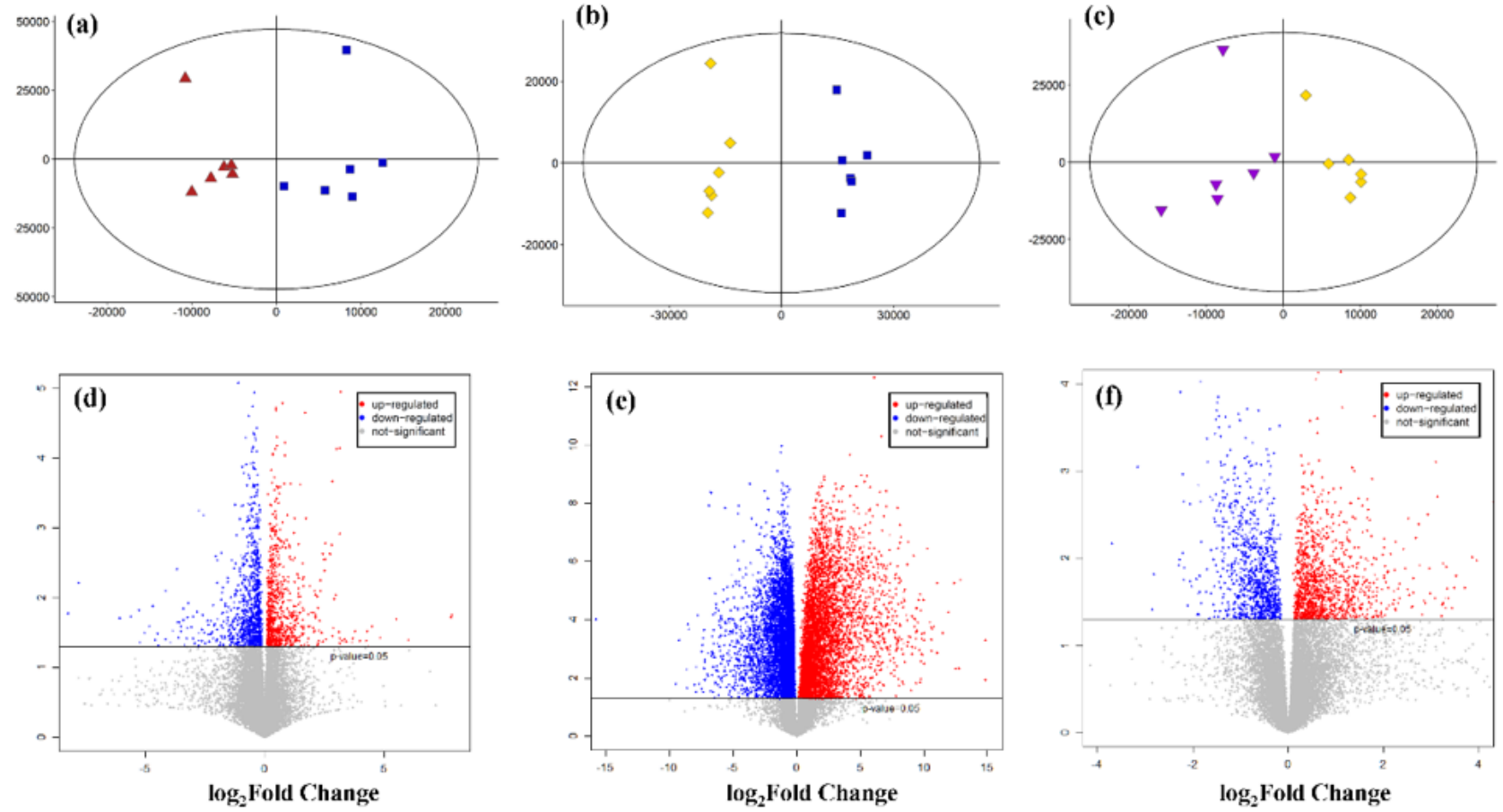

Page $12 / 13$ 
Figure 4

Metabolomics analyses of the different treatments. Score scatter plot of OPLS-DA model for group CK+B vs CK (a), CK+Cd vs CK (b) and CK+Cd+B vs CK+Cd (c); Volcano plot for group CK+B vs CK (d), CK+Cd vs CK (e) and CK+Cd+B vs CK+Cd (f).
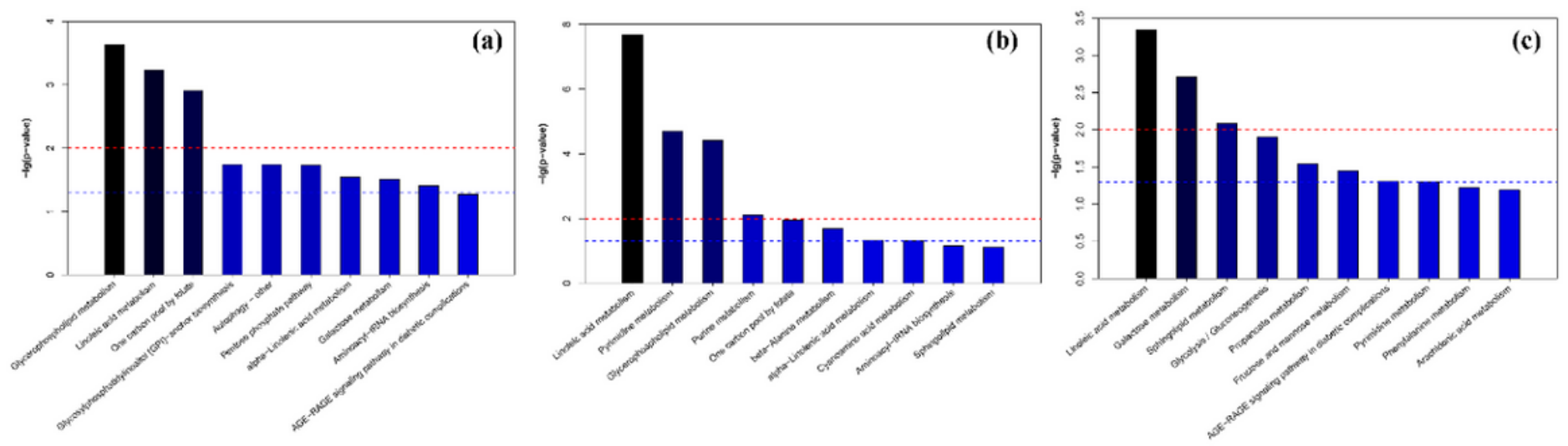

Figure 5

Metabolic pathway enrichment diagram of differential metabolites between CK+B and CK (a), CK+Cd and CK (b), and CK+Cd+B and CK+B (c). The p-value of the metabolic pathway is the significance of the enrichment of the metabolic pathway. The red line indicates a $P$ value of 0.01 , and the blue line indicates a $P$ value of 0.05 . It is significant for the signal pathway when the top of the bar is higher than the blue line.

\section{Supplementary Files}

This is a list of supplementary files associated with this preprint. Click to download.

- GraphicalAbstract.jpg 